\title{
Oral health conditions among pregnant women attended to at a health care center in Manaus, Amazonas, Brazil
}

\author{
Condições de saúde bucal de gestantes atendidas em uma \\ unidade de saúde em Manaus, Amazonas, Brasil
}

\begin{abstract}
Purpose: To evaluate the oral health conditions of pregnant women enrolled in the Prenatal and Birth Humanization Program of the Theomário Pinto Costa primary healthcare unit in the south-central zone of Manaus, Amazonas

Methods: The population comprised 50 pregnant women, independent of pregnancy trimester. To assess the prevalence of dental caries, we used the DMFT Index, and for gingivitis, we used the Plaque Index and Gingival Bleeding Index. A questionnaire was used to investigate socioeconomic conditions, access to dental services and self-perception regarding oral health.

Results: One hundred percent of the population presented with caries; the mean DMFT score was 10.0, and the M component (missing teeth) was predominant (4.28). Among the pregnant women examined, $62 \%$ presented with moderate gingival inflammation, and $64 \%$ presented with at least some plaque. With regard to educational level, $10 \%$ of the population had completed an elementary education, $20 \%$ had not completed an elementary education, $34 \%$ had completed a high school education, and $6 \%$ had not completed a university-level education.
\end{abstract}

Conclusion: Considering the results, it can be seen that the oral health status of the population was unfavorable, although a majority considered their oral health to be normal or good.

Key words: Pregnant women; oral health; prenatal care

\section{Resumo}

Objetivo: Avaliar as condições de saúde bucal de gestantes cadastradas no Programa de Humanização no Pré-natal e Nascimento (PHPN) na Unidade Básica de Saúde "Theomário Pinto Costa, situada na zona centro-sul de Manaus-AM".

Metodologia: A população estudada foi composta por 50 gestantes, independente do trimestre de gravidez. Para medir a prevalência de cárie utilizou-se o índice CPO-D e para gengivite foram utilizados Índices de Placa e Sangramento Gengival. Por meio de um questionário estruturado foram investigadas as condições socioeconômicas, o acesso aos serviços odontológicos e a autopercepção em saúde bucal.

Resultados: A população estudada apresentou $100 \%$ de prevalência de cárie com CPO-D médio de 10,0 sendo o componente $\mathrm{P}$ (dentes perdidos) predominante na composição do índice $(4,28)$. Das gestantes examinadas, $62 \%$ apresentaram inflamação gengival moderada e 64\% apresentaram placa mínima. O grau de escolaridade apresentou a seguinte distribuição: $10 \%$ ensino fundamental completo; $20 \%$ ensino fundamental incompleto; $34 \%$ ensino médio completo; $6 \%$ ensino superior incompleto.

Conclusões: Diante dos resultados obtidos, pôde-se constatar que as condições de saúde na população de gestantes estudadas foram desfavoráveis; entretanto, a maioria a considerou regular ou boa.

Palavras-chave: Gestantes; saúde bucal; cuidado pré-natal

\author{
Larissa Borges Bressane a \\ Lívea Nancy Bulcão da Silva Costa a \\ Janete Maria Rebelo Vieira ${ }^{a}$ \\ Maria Augusta Bessa Rebelo a
}

a Faculdade de Odontologia da Universidade Federal do Amazonas, Manaus, AM, Brasil

\section{Correspondence: \\ Maria Augusta Bessa Rebelo \\ Rua Rio ltannauá, 194/504 \\ Bairro Nossa Sra das Graças \\ Manaus, AM - Brasil \\ 69.053-040 \\ E-mail: augusta@ufam.edu.br \\ Received: January 2, 2011 \\ Accepted: October 16, 2011}

Conflict of interests: The authors state that there are no financial and personal conflicts of interest that could have inappropriately influenced their work.

Copyright: (C) 2011 Bressani et al.; licensee EDIPUCRS. This is an Open Access article distributed under the terms of the Creative Commons AttributionNoncommercial-No Derivative Works 3.0 Unported License. 


\section{Introduction}

The monitoring and care of pregnant women are among the most important public health activities in Brazil, as healthy and peaceful pregnancies are directly related to a decrease in mortality and to improvements in child health indicators and in quality of life for women (1).

As a systemic condition, pregnancy causes changes in the functioning of the human body as a whole and specifically in the oral cavity; these changes may favor the emergence of diseases, such as dental caries and periodontal disease. The presence of high levels of estrogen and progesterone during pregnancy has been identified as an aggravating factor for gingival inflammation in the presence of biofilm, predisposing women to the development of gingivitis gravidarum. Possible risk relationships between oral diseases, particularly periodontal disease, and pregnancy complications such as premature birth, low infant birth weight and pre-eclampsia have also been suggested in the literature $(2,3)$. In addition, higher colonization by Streptococcus mutans has also been observed in several studies of pregnant women, suggesting that there is relationship between the number of these bacteria in mothers and the risk of caries in their children (4-6).

According to the Brazilian Ministry of Health under the National Policy of Oral Health (7), at the beginning of prenatal care, pregnant women should be referred for dental visits that minimally include the following: counseling about the possibility of care during pregnancy, soft tissue examination and identification of risks to dental health, diagnosis of caries and assessment of the need for curative treatment, diagnosis of chronic gingivitis or periodontal disease and assessment of the need for treatment, as well as guidance regarding diet and oral hygiene. Under no circumstances should this assistance be compulsory, and the wishes of pregnant women should always be respected, under the threat of a penalty for serious ethical violations. In addition, referral for dental care is one of the recommendations for pre-natal care contained in the Technical Manual/Prenatal and Postpartum (8); ensuring the adequacy of the oral environment and controlling biofilm are additional preventive measures to ensure a comfortable pregnancy and continuity of care after pregnancy (9).

However, research $(10,11)$ has shown that a great number of pregnant women do not undergo dental visits during the prenatal period, and there are also high incidences of dental caries $(12,13)$ and gingivitis (14).

Additionally, inequalities in oral health among various regions of Brazil were observed using data obtained in the SB - 2002-2003 Brazil (15), which showed that the North and Northeast had more unfavorable oral health statuses and less access to dental services. Considering that national averages mask the social inequalities within each region, state, city or community, obtaining epidemiological data to quantify the oral health status of individuals at different regional levels is an important undertaking for managers.

Thus, the present study aimed to evaluate oral health status by estimating dental caries, plaque indices and gingival bleeding, identifying self-perceived oral health status and determining access to dental services in a population study.

\section{Methodology}

This was a descriptive and cross-sectional quantitative study, in which the primary data were collected from the population.

The city of Manaus, with a population of $1,802,014$ inhabitants (16), is divided into six zones, namely, the North, South, East, West, Central South and Midwest, which are organized for health care into four districts (North, South, East and West). The South district, particularly the areas covering the South and Central South zones, is characterized by great socioeconomic diversity, as it has some of the most affluent neighborhoods in Manaus as well as varying levels of poverty.

The basic health unit of Theomário Pinto da Costa was selected by convenience criteria. The unit is located in the Union neighborhood of the Central-South zone of Manaus, which offers a prenatal program and oral health to residents of the area.

The Research Ethics Committee of the Federal University of Amazonas authorized this study, under CAAE No. 0037.0.115.000-07. A Statement of Consent in accordance with Resolution 196/96 of the National Health Council was presented to the mother or guardian of participants younger than 18 years old to consent to participation in the study. Patients requiring treatment were referred to the unit staff for basic health care.

The sample comprised 50 pregnant women aged between 14 and 36 years old, who were enrolled in the prenatal program unit (regardless of trimester of pregnancy) in the period from November 2007 to March 2008. This number was based on the average number of pregnant women registered per month in 2006. The criterion for selection was a request by the women for appointments on days appointments were scheduled.

Before starting the activities, a calibration of examiner (related to the DMF-T Index) was undertaken. The same 20 patients were assessed and reassessed at the Clinic of the School of Dentistry, UFAM. The results of these tests were submitted to a Kappa statistical test, yielding a rate of 0.99 , indicating good reliability of the data collected by the examiner.

Clinical examinations were performed in the dental unit itself, using a No. 05 clinical mirror and CPI probe (recommended by the World Health Organization) for the Plaque Index and Bleeding Index. The study consisted of two parts: the clinical examination, which included an evaluation with the DMF-T Index (mean decayed, missing and filled teeth), the Plaque Index (IP) and the Bleeding Index (ISG) (17) as well as the administration of a questionnaire to the participants regarding socioeconomic conditions, access to dental services and self-perception of oral health.

For the qualitative data, absolute, relative and simple frequencies were calculated, in addition to quantitative 
means, medians and standard deviations. Epi-Info 3.4.3 software for Windows was used.

\section{Results}

The prevalence of caries was $100 \%$ in this population, considering that no pregnant women presented DMF-T indices equal to 0 . The average value for the index was 10.0 , and the most relevant component corresponded to missing teeth (M) (Table 1). A total of $68 \%$ of respondents had DMF-T indices greater than 7, which demonstrates the high caries incidence in this population.

Table 1. Mean and median of decayed teeth (D), missing teeth (M) and filled teeth (F) and of the DMF-T Index of pregnant women enrolled in the Program of Prenatal and Birth of the Basic Health Unit of Theomário Pinto Costa, Manaus, AM, Brazil.

\begin{tabular}{lccccc}
\hline \multicolumn{1}{c}{ Index $(\mathbf{n}=50)$} & Mean & SE & Median & Min. & Max. \\
\hline DMF-T & 10.00 & 5.99 & 9.00 & 1 & 28 \\
D & 2.52 & 2.42 & 2.00 & - & 12 \\
M & 4.28 & 5.19 & 2.00 & - & 24 \\
F & 3.20 & 3.42 & 2.00 & - & 12 \\
\hline
\end{tabular}

Considering the prevalence of gingivitis, no pregnant women had Gingival Index scores equal to 0 , which demonstrated that the entire population had some degree of gingival inflammation. No Plaque Index scores of 0 were observed, with the sample of pregnant women being divided between having minimal plaque $(0-1)$ or moderate plaque (>1 to 2$)$ (Table 2).

Table 2. Frequency and percentage of the classification of gingival inflammation (GI) and the Plaque Index (PI) of pregnant women enrolled in the Program of Prenatal and Birth of the Basic Health Unit of Theomário Pinto Costa, Manaus, AM, Brazil.

\begin{tabular}{lccc}
\hline \multicolumn{1}{l}{ Variables $(\mathrm{n}=50)$} & $\mathrm{f}_{\mathrm{i}}$ & $\%$ & IC $95 \%$ \\
\hline Gingival Inflammation (IG) & & & \\
$\quad$ Mild & 18 & 36.0 & $22.9-50.8$ \\
$\quad$ Moderate & 31 & 62.0 & $47.2-75.3$ \\
$\quad$ Severe & 1 & 2.0 & $0.1-10.6$ \\
Plaque Index (IP) & & & \\
$\quad$ Minimum & 32 & 64.0 & $49.2-77.1$ \\
$\quad$ Moderate & 18 & 36.0 & $22.9-50.8$ \\
\hline
\end{tabular}

Regarding socioeconomic characteristics, the majority of the pregnant women (60\%) had not completed high school, and $82 \%$ had attended public schools. More than half (56\%) owned their own homes, $44 \%$ had family incomes equal to 1 to 3 times the minimum wage, and $78 \%$ did not own an automobile (Table 3).
Table 3. Socioeconomic characteristics of pregnant women enrolled in the Program of Prenatal and Birth of the Basic Health Unit of Theomário Pinto Costa, Manaus, AM, Brazil.

\begin{tabular}{|c|c|c|}
\hline Variables $(n=50)$ & $f_{i^{\prime \prime}}$ & $\%$ \\
\hline \multicolumn{3}{|l|}{ Schooling } \\
\hline Elementary complete & 5 & 10.0 \\
\hline Elementary incomplete & 10 & 20.0 \\
\hline High school complete & 17 & 34.0 \\
\hline High school incomplete & 15 & 30.0 \\
\hline University incomplete & 3 & 6.0 \\
\hline \multicolumn{3}{|l|}{ Type of school } \\
\hline Public & 48 & 96.0 \\
\hline Private & 2 & 4.0 \\
\hline \multicolumn{3}{|l|}{ Type of housing } \\
\hline Owned & 28 & 56.0 \\
\hline Rented & 17 & 34.0 \\
\hline Other & 5 & 10.0 \\
\hline \multicolumn{3}{|l|}{ Number of rooms in the household } \\
\hline $1 \mid--3$ & 13 & 26.0 \\
\hline $3 \mid--5$ & 17 & 34.0 \\
\hline $5 \mid--7$ & 12 & 24.0 \\
\hline $7|--| 9$ & 8 & 16.0 \\
\hline Mean \pm SE & $4.2 \pm 2.1$ & \\
\hline \multicolumn{3}{|l|}{ Number of people in household } \\
\hline $2 \mid--4$ & 21 & 42.0 \\
\hline $4 \mid--6$ & 19 & 38.0 \\
\hline $6|--| 8$ & 10 & 20.0 \\
\hline Mean \pm SE & $4.2 \pm 1.9$ & \\
\hline \multicolumn{3}{|c|}{ Family income (Brazilian minimum wage) } \\
\hline $0--\mid 1$ & 6 & 12.0 \\
\hline $1---\mid 3$ & 22 & 44.0 \\
\hline $3---\mid 5$ & 12 & 24.0 \\
\hline$>5$ & 10 & 20.0 \\
\hline Mean \pm SE & $3.1 \pm 1.9$ & \\
\hline \multicolumn{3}{|l|}{ Own a car } \\
\hline Yes & 11 & 22.0 \\
\hline No & 39 & 78.0 \\
\hline
\end{tabular}

With regard to access to dental services, $96 \%$ of the pregnant women had undergone a dental visit at some time during their lives but not during the period of pregnancy. Concerning the location of the last dental visit, $60.4 \%$ claimed to have visited public clinics, $41.7 \%$ reported having sought treatment because of pain in their teeth, and $60.4 \%$ said they received information about the prevention of dental problems. Almost the entire sample (94\%) affirmed the need for treatment (Table 4).

Regarding self-perception, $42 \%$ rated their oral health as fair, $36 \%$ rated their teeth and gums as good, and $44 \%$ said that they had experienced no pain in their teeth or gums in the last 6 months (Table 5). The data on self-perceived oral health were different from those gathered from the clinical examinations of the pregnant women, indicating a low selfperception of treatment needs. 
Table 4. Description regarding access to dental services by pregnant women enrolled in the Program of Prenatal and Birth of the Basic Health Unit of Theomário Pinto Costa, Manaus, AM, Brazil.

\begin{tabular}{|c|c|c|}
\hline Variables & $f_{i}$ & $\%$ \\
\hline \multicolumn{3}{|c|}{ Have you ever been to a dentist? $(n=50)$} \\
\hline Yes & 48 & 96.0 \\
\hline No & 2 & 4.0 \\
\hline \multicolumn{3}{|l|}{ How long ago? $(n=48)$} \\
\hline Less than one year & 18 & 37.5 \\
\hline One to two years & 19 & 39.6 \\
\hline Three years or more & 11 & 22.9 \\
\hline \multicolumn{3}{|l|}{ Where? $(n=48)$} \\
\hline Public service & 29 & 60.4 \\
\hline Private & 18 & 37.5 \\
\hline Philanthropic service & 1 & 2.1 \\
\hline \multicolumn{3}{|l|}{ Why? $(n=48)$} \\
\hline Routine appointment & 11 & 22.9 \\
\hline Pain & 20 & 41.7 \\
\hline Cavities in teeth & 12 & 25.0 \\
\hline Others & 5 & 10.4 \\
\hline \multicolumn{3}{|c|}{$\begin{array}{l}\text { How would you evaluate the service? } \\
(n=48)\end{array}$} \\
\hline Awful & 3 & 6.2 \\
\hline Bad & 2 & 4.2 \\
\hline Regular & 6 & 12.5 \\
\hline Good & 25 & 52.1 \\
\hline Optimal & 12 & 25.0 \\
\hline \multicolumn{3}{|c|}{$\begin{array}{l}\text { Did you receive information on preventing } \\
\text { oral problems? }(n=48)\end{array}$} \\
\hline Yes & 19 & 39.6 \\
\hline No & 29 & 60.4 \\
\hline \multicolumn{3}{|c|}{$\begin{array}{l}\text { Do you think you need treatment today? } \\
(n=50)\end{array}$} \\
\hline Yes & 47 & 94.0 \\
\hline No & 3 & 6.0 \\
\hline
\end{tabular}

\section{Discussion}

Because a non-random sample was used, it is recognized that the external validity of this study is limited, and therefore, the results cannot be generalized to all of the pregnant women in the city of Manaus. However, the importance of the study should be considered, especially given the concomitant analysis of objective and subjective indicators related to oral health in pregnant women.

The prevalence of caries in the study population was $100 \%$, showing a high average score on the DMFT Index (10.0) and an average score of 2.52 on the component corresponding to decayed teeth (D). A similar score was found in the city of Aracaju - SE, Brazil, where pregnant women of low socioeconomic status had a mean DMF-T Index of 10.43 and an average D component equal to 1.43 (18).
Table 5. Description regarding self-perception of dental services by pregnant women enrolled in the Program of Prenatal and Birth of the Basic Health Unit of Theomário Pinto Costa, Manaus, AM, Brazil.

\begin{tabular}{|c|c|c|}
\hline Variables & $f_{i}$ & $\%$ \\
\hline \multicolumn{3}{|c|}{ Classification in relation to oral health } \\
\hline Awful & 6 & $\begin{array}{l}12.0 \\
12.0\end{array}$ \\
\hline Bad & 10 & 20.0 \\
\hline Regular & 21 & 42.0 \\
\hline Good & 13 & 26.0 \\
\hline \multicolumn{3}{|l|}{ Classification of teeth and gums } \\
\hline Awful & 3 & 6.0 \\
\hline Bad & 11 & 22.0 \\
\hline Regular & 14 & 28.0 \\
\hline Good & 18 & 36.0 \\
\hline Optimal & 3 & 6.0 \\
\hline Do not know/not reported & 1 & 2.0 \\
\hline \multicolumn{3}{|l|}{ Classification of chewing } \\
\hline Awful & 3 & 6.0 \\
\hline Bad & 8 & 16.0 \\
\hline Regular & 5 & 10.0 \\
\hline Good & 31 & 62.0 \\
\hline Optimal & 3 & 6.0 \\
\hline \multicolumn{3}{|c|}{$\begin{array}{l}\text { Classification of speech due to teeth } \\
\text { and gums }\end{array}$} \\
\hline Awful & 2 & 4.0 \\
\hline Bad & 5 & 10.0 \\
\hline Regular & 5 & 10.0 \\
\hline Good & 30 & 60.0 \\
\hline Optimal & 5 & 10.0 \\
\hline Do not know/not reported & 3 & 6.0 \\
\hline \multicolumn{3}{|c|}{$\begin{array}{l}\text { Oral health affecting relationships with } \\
\text { other persons }\end{array}$} \\
\hline Greatly & 4 & 8.0 \\
\hline More or less & 9 & 18.0 \\
\hline Little & 8 & 16.0 \\
\hline Does not affect & 27 & 54.0 \\
\hline Do not know/not reported & 2 & 4.0 \\
\hline \multicolumn{3}{|c|}{$\begin{array}{l}\text { Pain that caused the teeth and gums in } \\
\text { the last } 6 \text { months }\end{array}$} \\
\hline Much pain & 10 & 20.0 \\
\hline Average pain & 2 & 4.0 \\
\hline Little pain & 16 & 32.0 \\
\hline No pain & 22 & 44.0 \\
\hline
\end{tabular}

However, lower scores among pregnant women were found at two basic health units in the municipality of Porto Alegre - RS, Brazil, where the average DMF-T Index was 6.0 (19). The component of the DMF-T Index with the most significant value in the study population was $\mathrm{M}$ (4.28). This finding could be related to the influence of social class on clinical reasons for tooth loss, an association that has also been observed in the city of Maceió - AL, Brazil (20). It is 
noteworthy that in the present study, the dominant social classes were the typical and non-typical working classes, in which individuals without college educations sell their labor power in exchange for a salary (21).

According to the Bleeding Index scores, no pregnant women presented with a total absence of gingival inflammation. A total of $36 \%$ of the sample had mild inflammation, $62 \%$ had moderate inflammation, and $2 \%$ had severe inflammation, in disagreement with the results from another study of pregnant women from the Southeast region of Brazil, which reported a rate of $10 \%$ (12). As for the Plaque Index, the patients had either minimal plaque $(64 \%)$ or moderate plaque $(36 \%)$, and no pregnant women presented with a total absence of plaque. Thus, these results deserve attention because although periodontal changes have not yet been proved to constitute a risk factor for obstetric complications, the importance of maintaining the oral health of pregnant women, who should be capable of adequate oral feeding without bleeding (3), is not diminished.

Considering the socioeconomic status of the population studied, the results are consistent with the literature, which suggests an association between periodontal disease and certain indicators, such as income and education (22). Thus, the higher the educational level and the family income of the individuals studied are, the lower the prevalence of gingival bleeding is.

With regard to access to dental services, the vast majority of pregnant women (96\%) had undertaken a dental visit during their lifetimes, but $62.5 \%$ had had their last visits more than a year earlier. However, although none of the women sought dental care during their pregnancies, $94 \%$ of them affirmed that they needed treatment, and this percentage is close to that found in a population of schoolchildren in Manaus aged 15-19 years old (23). Pain was the main reason that pregnant women sought dental services $(41.7 \%)$, which is similar to the data found for schoolchildren (41\%) (23), and similar to data for the Northern region of Brazil (40.2\%), which has the highest percentage of dental health seekers among the Brazilian regions (15).
It is noteworthy that prenatal care consists of a set of clinical and educational procedures to monitor the evolution of pregnancy and to promote the health of pregnant women and their children, referring them for immediate care to the Unified Health System of Brazil (9).

Given the above, the data suggest that there may be barriers that make it difficult for this population to obtain care, such as folk beliefs that discourage the pursuit of dental care during pregnancy, the lack of a perceived need for treatment and fear of pain (11). At the same time, such myths and fears are sometimes reinforced by health professionals themselves (24).

Regarding self-perception, the largest percentage of the sample $(42 \%)$ rated its oral health as fair, and $26 \%$ rated it as good, which did not reflect the conditions found in the clinical examination. Similar findings were found in the southeast region of Brazil, where, despite a high caries incidence, great prosthetic need and a high incidence of calculus, patients perceived their oral health as satisfactory (12).

The results from objective indicators (DMF-T, IG, IP, access to dental care and socioeconomic status) reinforce the evidence that individuals with worse health conditions have limited access to health care. These data may be a reflection of socioeconomic inequalities among the different regions of Brazil.

\section{Conclusions}

According to the results obtained, it can be concluded that the pregnant women evaluated in this study had unfavorable oral health, although most of them considered their oral health fair or good.

\section{Acknowledgments}

This research was funded by the National Research Council - CNPq, through the Scholarship Program for Scientific Initiation of the Federal University of Amazonas, PIB - No. 021/2007.

References 1. Serruya SJ, Cecatti JG, Lago TG. O Programa de Humanização no Pré-natal e Nascimento do Ministério da Saúde no Brasil: resultados iniciais. Cad Saúde Pública 2004;20:1281-9.

2. Rosell FL, Montandon-Pompeu AAB, Valsecki Jr A. Periodontal screening and recording in pregnant women. Rev Saúde Pública 1999;33:157-62.

3. Passini Júnior R, Nomura ML, Politano GT. Doença periodontal e complicações obstétricas: há relação de risco? Rev Bras Ginecol Obstet 2007;29:372-7.

4. Caufield PW, Cutter GR, Dasanayake AP. Inicial acquisition of mutans streptococci by infants: evidence for a discrete window of infectivity. J Dent Res 1993;72:37-45.

5. Brambilla E, Felloni A, Gagliani M, Malerba A, Garcia-Godoy F, Strohmenger L. Caries prevention during pregnancy: results of a 30-month study. J Am Dental Assoc 1998; 129:871-7.

6. Torres AS, Rosa OPS, Akiyoshi N, Silveira AMM, Bretz WA. Níveis de infecção de estreptococos do grupo mutans em gestantes. Rev Odontol Univ São Paulo 1999; 13: $225-31$. 
7. Brasil. Ministério da Saúde. Secretaria de Atenção à Saúde. Departamento de atenção básica. Coordenação nacional de saúde bucal. Diretrizes da política nacional de saúde bucal. Brasília, 2004

8. Brasil. Ministério da Saúde. Secretaria de Atenção à Saúde. Departamento de Ações Programáticas. Área Técnica de Saúde da Mulher. Pré-natal e Puerpério: atenção qualificada e humanizada- Manual Técnico. Brasília, 2005.

9. Brasil. Ministério da Saúde. Secretaria de Atenção à Saúde. Departamento de Atenção Básica. Caderno de Atenção Básica à Saúde Bucal, n¹7. Brasília-DF - 2008

10. Ribeiro JM, Costa NR, Pinto LFS, Silva PLB. Atenção ao pré-natal na percepção das usuárias do Sistema Único de Saúde: um estudo comparativo. Cad Saúde Pública $2004 ; 20: 534-45$

11. Albuquerque OMR, Abegg C, Rodrigues CS. Percepção de gestantes do Programa Saúde da Família em relação a barreiras no atendimento odontológico em Pernambuco, Brasil. Cad Saúde Pública 2004;20:789-96.

12. Jeremias F, Silva SRC, Valsecki Junior A, Tagliaferro EPS, Rosell FL. Self-perception and oral health status in pregnant women. Odontol Cli-Cient, Recife 2010;9(:359-63.

13. Zanata RL, Navarro MF, Pereira JC, Franco EB, Lauris JR, Barbosa SH. Effect of caries preventive measures directed to expectante mothers on caries experience in their children. Braz Dent J 2003; 14:75-81.

14. Gomes ACZ, Paiva EMM. Inflamatory changes in the gingiva: is there a difference between pregnant and non-pregnants. ROBRAC 2000;9):4-8.

15. Brasil, Ministério da Saúde. Secretaria de Atenção à Saúde. Departamento de Atenção Básica. Coordenação Nacional de Saúde Bucal. Projeto SB BRASIL 2003: condições de saúde bucal da população brasileira 2002-2003. Resultados Principais. Brasília, 2004.

16. IBGE. Censo demográfico, 2010 (internet). Brasil: IBGE, 2010 (cited 2011 Sept. 29). Available from: http://www.ibge.gov.br/cidades.

17. Löe H, Silness J. Periodontal disease in pregnancy. I. Prevalence and severity. Acta Odontol Scand 1963;21:533-51.

18. Ramos TM, Almeida Jr AA, Ramos TM, Novaes SMA, Grinfeld S, Fortes TMV et al. Condições bucais e hábitos de higiene oral de gestantes de baixo nível socioeconômico no município de Aracaju-SE. Pesq Bras Odontoped Clin Integr 2006;6:229-35.

19. Rosa PC, Iser BPM, Rosa MAC, Slavutsky SMB. Indicadores de saúde bucal de gestantes vinculadas ao programa pré-natal de duas unidades básicas de saúde em Porto AlegreRS. Arquivos em Odontologia 2007;43:36-43.

20. Cimões R, Caldas Jr AF, Souza EHA, Gusmão ES. Influência da classe social nas razões clínicas das perdas dentárias. Ciênc Saúde Coletiva 2007; 12:1691-6.

21. Lombardi C, Bronfman M, Facchini LA, Victora CG, Barros FC, Béria JU et al. Operacionalização do conceito de classe social em estudos epidemiológicos. Rev Saúde Publica 1988;22:253-65.

22. Gesser HC, Peres MA, Marcenes W. Condições gengivais e periodontais associadas a fatores socioeconômicos. Rev Saúde Pública 2001;35:289-3.

23. Fonseca TGG, Lopes MC, Rebelo Vieira JM, Parente, RCP, Rebelo MAB. Caries experience in adolescentes from a meropolitan region of the Brazilian Amazon. Rev Odonto Ciênc $2009 ; 24: 349-53$

24. Codato LAB, Nakama L, Melchior R. Percepções de gestantes sobre atenção odontológica durante a gravidez. Ciênc Saúde Coletiva 2008;13:1075-80. 